\title{
Theoretical and Empirical Review on Sport Education Model (SEM) and Physical Self Concept (PSC) in Game Activities in Schools
}

\author{
Suherman Slamet* \\ Departemen Pendidikan Olahraga, Prodi PGSD Penjas \\ Universitas Pendidikan Indonesia \\ Bandung, Indonesia \\ *suhermanslamet@upi.edu
}

\begin{abstract}
This research plan is corroborated by several theoretical basis and research results that the right model applied by the teacher will provide convenience for students in learning. The application of strategies and approaches by the teacher to students must pay attention to the potential of the students, based on varied activities through games chosen according to the abilities of students. Sport Education Model (SEM) as a curriculum model that pays attention to direct learning which is student-centered has the aim to show the potentials that can be developed by organizing the class to be more directed, programmed, so that learning objectives will be achieved. The process of implementing student learning success based on several research results that reveal the self concept of physical self concept (PSC), is the most important thing that students want in learning to gain meaningful and meaningful learning experiences. Based on the findings of the research results the application of a sports education model and the student's physical concepts were tested to improve student learning outcomes in game activities, and were able to provide values of cognitive and affective understanding of students. Thus, theoretically and empirically the results of the sport education model (SEM) and Physical self concept (PSC) implementation become recommendations for teachers to improve the quality of physical education learning quality in elementary schools through game activities.
\end{abstract}

Keywords—sports education model; student self-concept; game learning activities

\section{INTRODUCTION}

The program of physical education learning in schools is currently applied in several learning models contained in the curriculum, students practice games and sports to participate students in learning motion according to contemporary theorization. This model proposes that sport education (SE) has the potential to promote a more positive cultural dimension of sports and physical activity and offer challenges to the real experiences of many institutionalized sports [1]. While very positive findings has been presented in research focusing on Sports Education organized by schools, about investigating how teachers as teaching and learning services in the new curriculum in physical education have been described as missing links in curriculum research [2]. sport is more like a completely different teaching style where teachers become facilitators in physical education learning [3]. Sport education model is explained that it is able to bring motivation and participation in physical education learning as a curricular model that supports independence, to stimulate students in extracurricular activities [4].

In the process of learning physical education as an intracurricular strengthened teacher intervention that the Sports Education Model (SEM) is an alternative to the second generation curriculum that is most prominent towards the direct teaching approach centered on teachers who are often dominant. The results of the study explain the aim of conducting a systematic analysis of two decades of research on sports education to identify critical conceptual and methodological problems and inform future directions for practice and research on the development of a more mature model. The scope of this essay covers the contextualization of contemporary shifts from teacher-to-student-centered approaches to teaching physical education [5].

Learning success can be measured based on student involvement in the learning process, so that students are able to develop their abilities. Thus Sport Education is the most widely implemented and researched pedagogical model in the world. Then Sports Education is the key to the results found. It was also emphasized that the specific configuration of the form of the game played by students could allow students to develop games [5]. Other studies emphasize that students can determine their own destiny and are interested in learning by using sports education models that aim to support students social relationships and motivation to engage in sports-based activities [6]. It was also explained that values would appear in learning in accordance with the results of the study that directly motivated the sports education program to improve physical activity and leisure time behavior. So the conclusion: Sports education facilitates forms of motivation for students who are more internalized in physical education programs that are needed, but without the provision of extracurricular classes that are appropriately designed, will not provide the potential for physical activity and leisure time may not be achieved [7]. This, the purpose of learning physical education must provide experience to develop positive, cognitive and psychomotor aspects. 


\section{METHOD}

The study was set as descriptive study since the study tried to explore the facts by making the responsible interpretation. The study was aimed at making description, systematic, accurate, and factual picture about the facts, characters, and the relationship between the investigated phenomenon through theoretical and empirical approach analysis on results of studies in relation to the practice of sports education in schools.

\section{RESUlT OF THEORETICAL AND EMPIRICAL ANALYSIS}

Physical education learning aims to improve academic, social, mental intelligence through physical activity, games, skills, in accordance with the evidence that exercise can also improve cognitive development and academic performance which provides other reasons for increasing physical activity for students. More specifically, this contains the need for quality physical education in schools because it allows all students to perform programmed (formal) physical activities at school [8], such as its philosophical position that recognizes skills learning that occurs in students by participating in physical activity, both in formal and informal situations. The use of the term "physical activity" here refers to participation in water activities, dance, sports, games, recreation carried out outside and indoors. The idea of two philosophers - John Dewey and Gilbert Ryle - will be referred to illustrate this philosophical position [9].

This physical education in primary schools must be maintained, identified what physical activity is needed by students in accordance with the results of the study described their pleasant physical activity (PAE) is relatively high, indicating that elementary school children usually enjoy their physical activities. This result is very valuable which shows that primary school children have positive physical concepts (PSC) which are important prerequisites for participating in physical activity [10].

\section{DISCUSSION}

\section{A. Sport Education Model (SEM)}

Sport education is a curriculum model that can be expanded far beyond the school to encompass many sport activities throughout the community [11]. Sport Education, developed by Daryl Siedentop is designed to provide authentic, educationally rich, sport experiences for girls and boys in the context of school physical education" [12]. Sport Education is a curriculum model that can be broadly developed both at school and outside the school (community) through (adopting) various kinds of activities that develop in the community (games and competitions). Siedentop said that "Has identified four basic assumptions originating in play theory that guide the selection and implementation of the sport education model (first) sport is an advanced form of play [11]. Second sport is an important part of our culture. Many people are involved in sport in an educational, recreational, or professional capacity. Third assumption states that, because sport is an integral part of our culture, students should learn sport as the subject matter of physical education. Fourth , participation in sport should be developmental. Many traditional sport activities should be modified to contribute to students' understanding and ability to play sport successfully.

\section{B. Physical Selft Concept (PSC)}

Physical self-concept in terms (PSC) that is Physical selfconcept According to the hierarchical model of Shavelson, Hubner, and Stanton, self-concept is a multidimensional construct made up of speci_c domains related to academic school subjects (Mathematics and German) and non-academic domains (social, emotional, and physical) [11], While PSC is a part of the non-academic self-concept comprising all selfperceptions of one's physical abilities. Based on Shavelson's and colleagues' model, Marsh, Richards, Johnson, Roche, and Tremayne developed the Physical Self-Description Questionnaire (PSDQ) measuring 10 facets of PSC: (1) Appearance, (2) Strength, (3) Endurance, (4) Health, (5) Coordination, (6) Physical Activity, (7) Body Fat, (8) Sport, (9) Flexibility, and (10) Global Physical. In addition, Global Self-Esteem (the overall feeling about one's self) was included [11].

Writing about self-concept (Self Concept) revealed by William James in Louis Cohen about "how one sees himself and what value is chosen for him (self-esteem) becomes important in determining the goals to be achieved by someone, the attitude chosen, the behavior shown, and the response made to others" [13].

The development of self-concept is also influenced by school experiences. The importance of the influence of the school is shown in the research that has been conducted, research focused on classrooms as a social system. This research has been sought to classify and measure the type and quality of teacher-student and student interactions in the classroom setting. In the opinion of Louis Cohen "For modern teachers, a clear picture of children self-concept becomes an important part of their professional knowledge and also their assessment of intellectual potential and academic progress of children". In game sports learning, the teacher needs to know the level of students self-concept, because the teacher can make plans that adjust the material, methods, media and assessment tools, so that students who have different selfconcepts will get the same knowledge [14].

Byrne noted that much of the interest in the selfconcept/achievement relation stems from the belief that academic self-concept has motivational properties such that changes in academic self-concept will lead to changes in subsequent academic achievement [15].

Some of the research results above explain the benefits and meaning of implementing a sports education model that currently. Sports Education is more successful in maintaining intrinsic motivation in a high level, task orientation, and climate control than traditional conditions. That is, Traditional conditions are associated with a decrease in the adaptive aspects of motivation for students, while the Sports Education condition maintains the existing level of motivation [16]. Sport Education is a curriculum model that can be widely developed both at school and outside school (community) by going through (adopting) various kinds of activities that 
develop in the community (games and competitions). Sports education is a curriculum and instruction model designed to provide authentic, educational, and rich sports experiences for girls and boys in the context of school physical education [12].

From several quotations from research results or journals that have published sports education is a model and can be applied to the curriculum in accordance with the explanation of research results that to present Sports Education, Tactical Games, and Cooperative Learning as valuable learning models in physical education. The learning that is located is used as a theoretical framework and the relationship between Sports Education, Tactical Games, and Cooperative Learning. Structure of Sports Education, Tactical Games, and Cooperative Learning make it possible to participate in student-centered learning curricula that conflict with the teacher-centered teaching curriculum. The teacher facilitates learning activities for students who have potential with holistic education that promotes social, physical and cognitive learning outcomes. The emphasis is on active learning that involves decision making processes, social interaction, and cognitive understanding for students [17].

Based on the explanation above, how the learning program is implemented with a sports education model must provide impact on students' self-development. The implementation of physical education learning in elementary schools currently needs special attention, whose orientation is to educate and equip activities that can provide meaningful knowledge, social, identity, and meaningful learning experience. The results show that heavy physical activity is not only healthy for students but also improves their cognitive abilities [18].

Physical education and sports contribute to the cognitive and social development of students in school. The importance of learning physical education and sports in schools is to develop cognitive and social potentials that are owned by students through motion activities, games and sports. [19]. The role of the teacher in teaching must also have good, structured, and systematic planning in game learning and adapted to students expectations when learning. The results of the study explain that techniques reveal and describe children's expectations; and this is identified through the development of children's thinking patterns that can provide a positive influence in regulating learning experiences that are appropriate and challenging, and also the importance of seriousness of learning in realizing direction and goals towards emphasizing learning and teaching activities [20]. It was also explained that children's participation in caring for themselves, beneficial in education, and playing activities are very important for their development, learning, health, and welfare [21].

Concerns Parents experience anxiety as an uncontrollable effect of the era of globalization, information, and technology and the lack of supervision over the freedom of electronic print media for example: television, mobile phones, etc., which can affect the growth and development of students in learning, especially in elementary schools. Deviant behaviors, violence, emotional disturbances that occur to students and teachers, this is a problem that occurs because the process of education in our school has a challenge to continue to improve the quality of education, from one of them through physical education learning. In accordance with the opinion of Adang Suherman physical education is education through and about physical activity or in the original language is physical education [22]. There are three key words in the definition, namely education that is reflected in the competencies students want to achieve through and about (through and of), as conjunctions that describe the closeness of the relationship expressed by direct and indirect relationships, and motion (movement), is a study material in the physical education curriculum. So the importance of physical education is applied in schools with several games and sports activities, so that students can learn to interpret and get physical benefits and values contained in them.

From a moral and behavioral perspective, the role of education that starts with the family, parents, siblings, friends, and environment will shape behavior and understanding when students learn. Of course with the role of the teacher in teaching that learning physical education must be centered on students who do not leave the curriculum as a teacher's guide to develop it (Learning and Teaching in Physical Education) In schools students are expected to get a second home after a home. Teachers or educators must be concerned about this matter, in accordance with the results of the research described in the following journal is a good time to detail personal approaches to the challenges faced by teachers when facing the demands of the weight of the teaching burden. For this reason, the focus here on teacher responsibility with regard to Physical Education is the call to see personal practice and to clarify the teachers own understanding of what is needed if they serve the physical needs of certain children who are their responsibility [23]. The explanation is that the teachers responsibilities are very heavy in terms of how well students are educated in their behavior, knowledge, and physical.

To gain knowledge through learning physical education, "Children with better mastery of physical health knowledge tend to engage in healthy health" [24]. Parents in general have trusted the school of choice in accordance with the expectations of their dreams, so that their children will become good and outstanding children. This is not enough children who excel in academics, but now how schools are able to provide education that is able to instill social values that hope for character building or a good attitude. Based on the results of the study explained that provides initial validation of honesty values for children that affect changes in the moral development of elementary school students [25].

Physical Education is a subject that is able to provide a concept of understanding, social, knowledge and provide a motion experience through activities that are in accordance with the physical abilities of students, which can influence the growth and development of children when learning. In accordance with the results of the study described in the paper analysis stated that there was only one major shift in ideas of physical education from the beginning as a school subject; namely from physical education such as gymnastics to physical education as sports skills [26], therefore based on the findings of other studies in order to encourage physical education teachers not to miss concept in applying the understanding of motion for physical health, to overcome 
learning barriers that provide value potential brought about by concepts, and misunderstanding of students ignorance/pretense [27]. That students understanding when learning physical education needs to be improved through a variety of motion activities to equip useful knowledge and the function of movement for the body and the development of its behavior in a positive direction, so that it will be revealed personally what students respond. As described in the results of a journal study: pleasure seems to be an important factor for the implementation of pleasant physical education. However, after the transition, many children begin to describe pleasure in learning challenges rather than in relation to hedonic responses to games [19]. For each physical education learning must be able to describe the basic abilities of students initial understanding and knowledge as a provision for dealing with their positive world life.

\section{CONCLUSION}

The implementation of physical education learning in Sport education model (SEM) will provide hands-on experiences that are directly learned by students, many of which are learned such as leadership, involvement, competitiveness, and most importantly students can develop cognitive, effective and psychomotor values., which is based on Physical self concept (PSC) which is the result of selfimage of students who make a reference for teachers to design physical education learning that will be in accordance with the objectives to be achieved. Through the selection of appropriate game activities will also provide passion and motivation for students in effective learning.

\section{REFERENCES}

[1] Wallhead, T., \& O'sullivan, M. (2005). Sport Education: physical education for the new millennium? Physical Education \& Sport Pedagogy, 10(2), 181-210.

[2] Hentati, A., \& Elloumi, A. (2013). Tunisian validation of a measuring instrument: Physical Self- Description Questionnaire (PSDQ). IOSR Journal Of Humanities And Social Science, 11(1), 79-88

[3] Glotova, O. N., \& Hastie, P. A. (2014). Learning to teach Sport Education in Russia: factors affecting model understanding and intentions to teach. Sport, Education and Society, 19(8), 1072-1088.

[4] Hagger, M., \& Smith, D. T. (2010). Sport education and extracurricular sport participation: An examination using the trans-contextual model of motivation. Research Quarterly for Exercise and Sport, 81(4), 442-455.

[5] Hastie, P. A., Maria, I., \& Mesquita, R. (2012). The Sport Education Model: Research update and future avenues for practice and investigation $\mathrm{O}$ Modelo de Educação Desportiva: Atualização da investigação e futuras avenidas para a intervenção e investigação, 1(2001), 73-79.

[6] Perlman, D. J. (2011). Examination of self-determination within the sport education model. Asia-Pacific Journal of Health, Sport and Physical Education, 2(1), 79-92.
[7] Wallhead, T. L., Garn, A. C., \& Vidoni, C. (2014). Effect of a sport education program on motivation for physical education and leisure-time physical activity. Research Quarterly for Exercise and Sport, 85(4), 478487

[8] Sattelmair, J., \& Ratey, J. J. (2009). Physically Active Play and Cognition: An Academic Matter? American Journal of Play, 366-374.

[9] Johnson, T. G., \& Turner, L. (2016). The Physical Activity Movement and the Definition of Physical Education. Journal of Physical Education, Recreation \& Dance, 87(4), 8-10.

[10] Lohbeck, A., Tietjens, M., \& Bund, A. (2016). Physical self-concept and physical activity enjoyment in elementary school children. Early Child Development and Care, 186(11), 1792-1801.

[11] Jewett, R., Sabiston, C. M., Brunet, J., O'Loughlin, E. K., Scarapicchia, T., \& O'Loughlin, J. (2014). School sport participation during adolescence and mental health in early adulthood. Journal of adolescent health, 55(5), 640-644.

[12] Siedentop, D. (1998). What is sport education and how does it work? Journal of Physical Education, Recreation \& Dance, 69(4), 18-20.

[13] Shavelson, R. J., Hubner, J. J., \& Stanton, G. C. (1976). Self-concept: Validation of construct interpretations. Review of educational research 46(3), 407-441.

[14] Cohen, L., Manion, L., \& Morrison, K. (2002). Research methods in education. routledge.

[15] Tracey, D., \& Marsh, H. (2000). Self-Concepts of Primary Students with Mild Intellectual Disabilities: Issues of Measurement and Educational Placement. Self-Concept Theory, Research and Practice: Advances from the New Millennium.

[16] Spittle, M., \& Byrne, K. (2009). The influence of Sport Education on student motivation in physical education. Physical Education and Sport Pedagogy, 14(3), 253-266.

[17] Dyson, B., Griffin, L. L., \& Hastie, P. (2004). Sport education, tactical games, and cooperative learning: Theoretical and pedagogical considerations. Quest, 56(2), 226-240

[18] Sattelmair, J., \& Ratey, J. J. (2009). Physically Active Play and Cognition: An Academic Matter? American Journal of Play, 366-374.

[19] Dismore H., \& Bailey, R. (2010). "It"s been a bit of a rocky start' attitudes toward physical education following transition. Physical Education \& Sport Pedagogy.

[20] Willig, C. J. (1990). Children's concepts and school learning. Early Child Development and Care, 57(1), 89-99.

[21] Goltz, H., \& Brown, T. (2014). Relationship between Children's Physical Self-Concepts, Activity Preferences, and Occupational Participation. Journal of Occupational Therapy, Schools, and Early Intervention, 7(January 2015), 260-271.

[22] Suherman Adang (2009) Revitalisasi pengajaran dalam pendidikan jasmani CV Bintang Warli Artika Bandung.

[23] Price, L. (1995). Physical education for 4???7 year olds. Early Child Development and Care, 109(1), 133-142.

[24] Hamilton, M. E., \& Coulby, W. M. (1991). Oral health knowledge and habits of senior elementary school students. Journal of Public Health Dentistry, 51(4), 212-219.

[25] Gibbons, S. L., Ebbeck, V., \& Weiss, M. R. (1995). Fair Play for Kids : Effects on the Moral Development of Children in Physical Education. Research Quarterly for Exercise and Sport, 66(3), 247-255.

[26] Tinning, R. (2011). Physical Education and Sport Pedagogy The idea of physical education : a memetic perspective, (October 2014), 37-41.

[27] Zhang, T., Chen, A., Ennis, C., \& Zhang, T. (2017). Elementary school students naïve conceptions and misconceptions about energy in physical education context misconceptions about energy in physical education context. Sport, Education and Society. 